\title{
Tribes, Government and History in Yemen
}

\section{By Paul Dresch. Oxford: Oxford University Press, 1989.}

This book is complex and, at points, obscure. Yet it is also an exceptionally rich collection of information about tribal identity and ethos in Yemen and, for scholars with a special interest in Yemeni society, can be a valuable resource. The author orients much of his material toward two main questions, neither of which is formulated explicitly: How can tribal political organization and state legal institutions co-exist, not only for brief moments but for over 1,000 years? and How have the names and boundaries of tribal territories been preserved with little change for such a long time?

The answer to the first question is on p. 165: ". . . the hijrah [in Yemeni Arabic: a protected space or person] provided the point around which both states of the world turned: strong Imams [heads of state] and weak. It could do so 
because it meant different things to different people." The first 150 pages of the book, especially chapters 2 ("The Language of Honour"), 3 ("Tribes and Collective Action") and 4 ("Estates of Society within the Tribal Peace"), lead up to and persuaded us to accept the conclusion that the mutual recognition by the state and by the tribes of neutral zones and people in tribal territories facilitated trade, tribe-state communication, and contact between literate Islamic specialists and illiterate farmers and stock-breeders. Even when the interests of the tribes and the state were directly opposed (for instance, in controlling roads and determining rates of taxation), violent conflicts between tribe and state were kept partly in check by tribal custom, just as they were when tribe clashed with tribe (see pp. 267, 268, 379-387).

Much of Dresch's argument rests on his interpretation of various Arabic terms (sharaf, 'ard, wajh, 'ayb, 'ār, and nämüs) that can be glossed as "honor" or "shame." Similar attempts to explain social order as the expression of abstract moral concepts were made in the 1970 s by Peristiany and others. What is new in Dresch's account is his use of the medieval English notions of peace (the "King's peace," "the peace of the church") to link these concepts so that they form a legal and moral structure which, he claims, supports the institution of hijrah (pp. 92-97, 145-150). He resurrects obscure English terms (ex. mulct rather than "fine") to add to his implicit comparison with England. The profit from this particular comparison is clear: It makes us take a fresh look at early medieval England and see how its own tensions between tribe and canon/state law were worked out. Thus, Yemen appears less exotic to Europeans and serves as an antidote to ethnocentrism. However, other cross-cultural comparisons (particularly between Yemeni tribes and the Moroccan tribes studied by David Hart) would also have been illuminating. But Dresch does not spell out his rationale for preferring England to Morocco as a foil for his analysis; as usual, his arguments are implicit.

Although Dresch's thesis about "tribal honour" is plausible, one feels a little weary at seeing yet another debate about the meaning of these abstractions since it cannot, by its nature, ever be conclusive; the tribesmen themselves have similar debates. Another approach would be to study the rhetorical strategies of people who refer to such abstractions in specific discursive contexts, to see how they are used to advance personal material interests.

Dresch answers the question of how tribes persist with little change by showing how, in modern times, a village or group can change its allegiance from one territorially-fixed tribe to another without changing its residence. $\mathrm{He}$ also explains how tribes remain in one place, despite the movement of their members, by demonstrating that the hierarchy of groups and sub-groups can be redefined so that tribal "genealogies" retain their match with tribal territories. Although these solutions may seem complicated when summarized so briefly, they are clear when read in full.

One of my quarrels with the book involves its surprisingly casual treatment of Islamic thinking (especially in comparison with its scrupulous ethnography of tribal mores). He accepts the idea, for example, that both "tribalism" and "Zaydi" Islam were a kind of "da"wa, or summons to action" (p. 30). But this is to mistake a verbal noun (dawa, "summons," "invitation") for a predicate (alda'wa ila al-haqq, "a summons to the Truth.") Although we may disagree on what the Truth is, we know that it is not simply "action" nor, in particular, the action taken by a group merely to restore their collective honor. The ontological 
claims of tribes and religious scholars are very different. And although Dresch is correct when he observes that Yemeni tribal custom and Islamic law often are in agreement (p. 183), he forgets to add that Islam is not only a legal system but has a cosmology and ritual observances quite at variance with those of the tribes. $\mathrm{He}$ minimizes the contradiction between tribal values and universalistic Islam by opposing local custom to "Zaydism" and "the Imamate" (which could also be characterized as merely local, hence, on the same footing as the tribes). Surely the rural fuqaha (whom Dresch calls "learned men" or, more scornfully, "scribes"; pp. 131, 195) do not think of themselves as "Zaydis."

Another difficulty is the author's unwillingness to tell us up front what his arguments are. He justifies this by citing E. E. Evans-Pritchard, who believed that the very arrangement of facts in an ethnography constituted its analysis, so that no formal argument was necessary (p. ix). Yet perhaps Dresch shrank from explicitly stating his theses about tribal longevity and the tribe-state polarity because he felt it would confine him to a disappointingly short range of topics. In fact, parts of his book (for example, his diligent study of traditional Yemeni agricultural techniques and their lexicon, and his description of a village's economy, in chapter 8) have no obvious connection to the book's main problem. Although these findings are excellently presented, they have almost no place in the scheme of the book.

Dresch's translations of Arabic are generally good, although he makes a few mistakes. Some are trivial, for example, on pp. 80 and 139, shall/yushill, "to paralyze," should be shäl/yashïl, "to carry away"; on p. 62, salimt, should be (from the context) "you are safe," not "I am safe"; and on p. 63 "äfäkum, should be "God grant you health ("äfiya)," not "God spare you." Some other mistakes are more consequential. For instance, he translates hajr al-haräm wa al-ihrām as "to restore the status of the (sacred) enclave and of the (inviolable) pilgrimage" ( $\mathrm{p}$. 146). I would prefer "to protect from violation the sacred enclave and the liminal status (ihräm) of the pilgrims." In other words, what is at stake here is the protection of places and persons, not ritual acts like the pilgrimage (which cannot, logically, be protected but can only be performed or interrupted). This translation accords better with Dresch's thesis about the institution of hijrah; his more casual gloss deprives him of support for his own argument. Also, he reports that "... when there is no strong figure to constrain men, they complain that 'everyone rules himself' ... kull wähid yahkum 'alä nafshu.... Were a middle-class Englishman ... to complain of disorder, it would surely be to say just the opposite: that everyone fails to rule himself, that self-restraint was lacking and the common good therefore threatened" (p. 100). However, the Arabic phrase does not bear this implied contrast between Englishmen and Yemenis. It means "Everyone passes judgement on himself," i.e., decides whether he is right or wrong, ignoring communal and/or Islamic standards of judgment; "everyone rules himself" would be: kull wähid yahkum nafsahu. Thus the Englishman and the Yemeni do not seem so different after all.

My final quarrel with the book concerns its philosophical idealism, which verges at times on nominalism. At many points he implies that the real world and the world of the imagination blend into each other seamlessly. For example, he says "Being a tribesman is as much a work of the imagination as a simple fact to be borne with" (p. 14), and "What the outsider might wish to distinguish as real and imaginary ... cannot be separated without losing the significance of much that tribesmen do" (p. 42). By adopting such a position, Dresch finds it 
difficult to maintain a distinction between abstract and concrete (empirically visible) things. So, for instance, when he discusses the Western boundary of the Hāshidì tribal territories (which is also the dividing line between tribal and nontribal societies in Yemen), he says that "a line is almost visible to the eye" (p. 26). Well, is it visible or not? It cannot be both visible (concrete) and invisible (abstract) at once. He goes on to explain that, "to the east of it ... mosques are usually simple cubes, often attached to people's houses; to the west of it they are usually more elaborate, domed structure reminiscent of Lower Yemen or indeed of North Africa" (p. 26). Clearly what he means is: People can read architectural features as markers of tribal or nontribal organization and, abstracting these features from the empirical environment, construct in their minds' eye an abstract line. It is not visible.

Dresch does not always confuse the abstract with the concrete. He recognizes, for example, that a "village" is an abstract object, a conceptual entity that is mapped onto the concrete valleys, houses, and roads which are said to belong to it (pp. 332-323). But when it comes to "tribe" he wavers. He says that tribes are "elements in the language of honour" (that is, are abstract) and points out that they "are taken to be geographically fixed (there is no rhetoric of conquest or displacement)" and that "Tribes never explicitly win territory from others" (pp. 77-81). But, rhetoric aside, were there any actual conquests or displacements? Surely the concrete events-killings, burnings of fields and houses, expulsions of people- that we normally identify as elements of a conquest cannot be constructed out of mere words. Rhetoric can, it is true, serve for constructing and reconstructing abstractions such as "justice," "democracy," "obedience to God," "eternity," and so on, but to claim that rhetoric can also be used to construct actual events is pure nominalism.

Dresch does not go this far. Yet he mixes abstractions with concrete things, and rhetorical references with empirical observations, in an inconsistent way, bracketing a few rhetorical references with scare-quotes and leaving other, equally rhetorical tropes unmarked. For example, on p. 14 he says that "many of the values to which tribesmen claim adherence are best exemplified in stories of wonders and heroic deed, which . . . occurred ... in some other place [such as]...the Jawf. ... It is there ... that one will find the authentic . . . customs and the 'real' tribesmen.... Further westward ... is the Tihämah ... populated by ... people whom tribesmen are inclined to talk of as being "abid (slaves, or at least sons of slaves), which in fact rather few of them are." Why bracket "real" and not "tribesmen" and "slaves"? All are English glosses of local terms whose meaning can only be determined discursively. In Yemen such terms do not refer to individual people in a simple, immediate way but place them in particularistic social ("emic") categories (to use anthropological jargon). Dresch knows this; he refers to tribal names and locations as a "conceptual order" (p. 29). But he often writes as if this conceptual order goes "all the way down" to empirical reality and that no objective knowledge of the concrete world is possible (see p. 37 , n. 33 and p. 172).

Dresch's leanings toward nominalism complicate unnecessarily his arguments about the tribes' attitudes toward the Yemeni state/the Imamate/the "Zaydi" legal tradition (all of the which Dresch treats as a unified entity). He states, for example, that "one cannot ... find an 'elective affinity' between Zaydism and the tribes [in the accounts of history written by Zaydi historians], because the relation between them is in large part defined by Zaydism itself" (p. 166). By 
"elective affinity" does he mean (1) a logical harmony between "Zaydi" legal traditions and the tribal moral order, (2) a practical accommodation between the interests of the tribes and those of the Zaydi Imams and scholars, or (3) a working coordination of the tribes' concrete political actions with those of the head of state, despite differences in interests?

Even if we leave this question unanswered, we still need to know how "Zaydism" itself can "define the relation" between "Zaydism and the tribes." Logically, if one wants to determine whether this "elective affinity" was present, one must assume that the relation existed (or did not exist) independently of the rhetorical claims made by "Zaydi" writers about it. That is, if "Zaydi" historiography is so biased or incomplete that no evidence of a correspondence between Zaydi law and tribal morality during a particular period can be found, this does not imply that no such correspondence existed. It only means that we cannot decide what was the case by using "Zaydi" historical materials. If the history of Yemen's tribes and state has any ground in real events that actually happened, then this history is not simply a rhetorical construction. There is a difference between "Zaydi" historiography and Yemen's history. "Zaydi" historiography cannot define this history; it can only reveal or conceal it.

In sum, this book is far from a straightforward account of Yemeni tribal societies and their history. It contains a great deal of interesting ethnographic data. These are often presented, however, as transcendental generalizations that float above the Yemeni landscape. I have no doubt that they are grounded in social realities but wish that Dresch had taken more care to place them in actual discursive contexts. Anthropologists can use the book to deepen their understanding of Yemeni concepts and social categories. Scholars from other disciplines can benefit from its thorough exploration of culture-specific codes and models of social order. But the book falls short of a convincing explanation of Yemeni political actions. It illuminates these actions and allows us to perceive their special logic more clearly but it does not reveal the underlying motivations or causes.

William C. Young Department of Sociology and Anthropology Georgia Southern University Statesboro, Georgia 